\title{
The press struggles for credibility in the face of info-toxification: new strategies emerge to counter decentralized hoaxes
}

\section{La prensa lucha por la credibilidad ante la info-toxificación: nuevas estrategias para contrarrestar los engaños descentralizados}

\begin{abstract}
:
The emergence of search engines and social media networks in the past two decades created a new media ecosystem that allowed the instantaneous creation, distribution, manipulation, and sharing of content to a global audience by anyone with a smartphone and internet access. This ecosystem was ripe for exploitation by actors with aims of profit or propaganda to disrupt society and threaten democratic processes. Their disinformation sowed distrust and undermined the credibility of the press. The dispersed, decentralized nature of this communication has made it hard to police. However, new countermeasures are emerging based on international collaboration on systems for rating trustworthiness of publications and journalists. The technology platforms are collaborating on some of these efforts, but are resisting efforts to have regulators interfere with their business model.
\end{abstract}

\section{KEY WORDS:}

Misinformation; Disinformation; Social networks; Search engines; Regulators; Hoaxes.

\section{RESUMEN:}

La aparición de motores de búsqueda y redes sociales en las últimas dos décadas creó un nuevo ecosistema de medios que permitió la creación, distribución, manipulación e intercambio instantáneo de contenido a una audiencia global por cualquier persona con un teléfono inteligente y acceso a internet. Este ecosistema estaba apto para ser explotado por actores con fines de lucro o propaganda para alterar la sociedad y amenazar los procesos democráticos. Su desinformación sembró desconfianza y minó la credibilidad de la prensa La naturaleza dispersa y descentralizada de esta comunicación ha dificultado su vigilancia. Sin embargo, están surgiendo nuevas contramedidas basadas en la colaboración internacional en sistemas para calificar la confiabilidad de publicaciones y periodistas. Las plataformas tecnológicas están colaborando en algunos de estos esfuerzos, pero se resisten a hacer que los reguladores interfieran con su modelo de negocio. 


\section{Introduction}

Hardly a day goes by without some journalist or media maven expressing high anxiety over what they are seeing in the mainstream media, some social network, or a dark corner of the less traveled regions of the internet. Driving and heightening this anxiety are the events of the moment (October of 2020). The world is living through two extreme disruptions--a deadly pandemic that is infecting millions and has no cure or vaccine, which in turn is causing an economic downturn not seen since the Great Depression. Add to those crises the tangled Brexit saga that has fractured relations between Great Britain and its largest trading and defense partner, and pile on a series of bitterly contested elections, not the least of which involves the presidency of the world's largest economic and nuclear power. Who would not be susceptible to anxiety if not panic?

The anxiety takes many forms. Some wonder how we might be being manipulated by state actors whose propaganda is designed to undermine our faith in our institutions, including the Fourth Estate and the democratic process. Others want to blame the algorithm-driven profitmaking machines of advertising on search engines and social networks for creating polarized camps that pit extreme views and create a space where only black and white exist. Others study the problem by applying principles of mass psychology and the human instinct to frame the world into two camps, us vs. them. Still others explain the issue from the point of view that there is simply a lot of money to made peddling sensationalist content that provokes reactions of fear, derision, hatred, and uncertainty. Then, there are the data scientists who use new tools to track the spread of information through these new networks to try to trace their origin, understand which nodes of connections are the super spreaders, and then propose solutions and strategies for combating this misinformation.

This paper will describe the many forms of info-toxification, which is the spread of misinformation that damages health and democratic institutions. It will also study some of the actors and channels through case studies. Finally, it will attempt to create road map of solutions toward solving this problem, so dangerous to the credibility of the press and democratic institutions.

\section{Many forms and tools of misinformation and disinformation}

Before social media and search engines, journalists controlled a great deal of information that was made available to the public. From the point of view of journalists, the issue of what is true and what is false boils down to what can be documented and verified from authoritative, credible sources. And those sources themselves have to be continually verified. Good journalism doesn't pretend to be the Truth with a capital T. Journalism is rather an ongoing pursuit to understand and contextualize events, subject to constant modification as new information can be obtained and verified. Journalistic codes make a distinction about objectivity: it is not the journalist who is objective, but the process that is objective, based on a review of evidence from as many sources and points of view as possible. It is the nature of journalism that it is a «first draft of history». And, like history, it has to be revised when new information is discovered and verified.

The study of misinformation and disinformation is not new, but it has acquired greater focus of public attention in particular after the 2016 Brexit referendum in the UK and the 
election later that year of Donald Trump as president of the US. In both of those elections, orchestrated disinformation campaigns received extensive media coverage, some of which placed the blame on state actors such as Russia or political actors opposed to immigration. There have been several attempts to create a typology of these kinds of information. The famous «fake news» label does not begin to capture the nuances.

\subsection{FAKE NEWS: A MULTITUDE OF SINS}

Wardle (2017) captured the essence of the problem of developing a typology of false or misleading information in the title of her article on the topic, «Fake News: it's Complicated». Wardle is the director of First Draft, a nonprofit research organization whose mission is to «protect communities from harmful misinformation». She differentiates between the types of content being created, the motivations of the people creating and spreading the content, and the channels of dissemination. She maps the types of misinformation on a continuum and identifies seven types: satire or parody, with humorous intent; false connection, when headlines don't support the content; misleading content in the framing of an issue or person; false context, when genuine information is shared with false contextual information; impostor content, when genuine sources are impersonated; manipulated content, when genuine information or imagery is manipulated to deceive; and fabricated content, which is $100 \%$ false and is designed to deceive and do harm.

These categories themselves need to be further differentiated, based on who is spreading the misinformation and why, Wardle says. Some of it is being shared unwittingly by people on social media, who click on retweet without checking. Some of it is being amplified by journalists under more pressure than ever to accurately report information emerging on the social web in real time. Some of it is being pushed out by loosely connected groups who are deliberately attempting to influence public opinion, and some of it is being disseminated as part of sophisticated disinformation campaigns

\subsection{False information about Covid-19 in Spain}

A study of of false information being spread in Spain from mid-March to mid-April during the covid-19 lockdown identified four types of hoaxes: jokes, exaggeration, decontextualization, and deliberate deception (Salaverria et al., 2020: 10). The study tracked 395 articles factchecked by three reputable Spanish fact-checking organizations. It found different types of false information depending on the target audiences of the media organizations. At the international level, the articles focused on spreading misinformation about health or science. But at the national and local level, the false information was aimed to discredit individual politicians or public servants for their management of the crisis.

\subsection{TeChNOLOGy AND DATABASE StRATEgIES OF Misinformation}

The typology developed in the Shorenstein Center's Media manipulation casebook (2020) includes several categories similar to Wardle's, and goes further to describe some of the tools and techniques used. A notable one is "keyword squatting", which involves creating online content and social media accounts around a specific search-engine-optimized term. 
A publisher with intent to misinform can then, in effect, siphon off some of the traffic to that term and direct people to its own content on the subject. Another tool, called an evidence collage, «is a collection of screenshots and text that is assembled into a shareable document and presented as evidence. No professional computer applications are required». The publisher then directs users to sites with more misinformation. While many media observers worry about the sophisticated manipulations known as deep fakes, which require advanced technology and machine learning, this report points out the more immediate danger of «cheap fakes». A cheap fake is "altered media that has been changed through conventional and affordable technology» such as photoshopping, face swapping, and speeding up or slowing down a video. Virtually anyone can do it.

\subsection{The SUBCULTURE OF CONSPIRACY}

Marwick y Lewis (2017: 1) described how right-wing groups that promote conspiracy theories have created their own media subculture. It interacts little with mainstream outlets, which they avoid for being, among other things, «too politically correct». Young, single men who feel disconnected from mainstream culture are particularly susceptible to the messages, which often have an anti-feminist and anti-authoritarian bent. These counterculture media operate in the dark corners of the internet, but their messages can be surfaced at opportune moments for political ends. Right-wing actors

take advantage of the current media ecosystem to manipulate news frames, set agendas, and propagate ideas. Far-right groups have developed techniques of «attention hacking» to increase the visibility of their ideas through the strategic use of social media, memes, and bots-as well as by targeting journalists, bloggers, and influencers to help spread content (p. 1).

Mainstream media can be unwittingly manipulated into amplifying fringe conspiracy theories because they often base story selection on social media trends and have a financial incentive to promote traffic-boosting sensationalism, novelty, and clickbait.

\section{The vicious cycle of distrust, conspiracies, and monetization}

These typologies of misinformation suggest that widely different motives drive the various actors who contribute to the misinformation ecosystem. They range from the innocent and fun-loving to the viciously partisan and financially driven. The variety is one of the problems with trying to control it and understand it. The motivations and actors are as varied as human beings themselves, but they can be grouped into general categories along a spectrum, and they make use of a wide variety of distribution techniques and channels, as we have described. The media ecosystem today seems receptive to misinformation. As Gallup polls over several decades have shown, public trust in the news media has declined steadily in the US (Swift, 2016). The Reuters Institute's 2018 Digital News Report, based on surveys in 38 countries around the world, found that many years of digital disruption have 
undermined confidence of both publishers and consumers. Our data show that consumer trust in news remains worryingly low in most countries, often linked to high levels of media polarization, and the perception of undue political influence. Adding to the mix are high levels of concern about so-called "fake news", partly stoked by politicians, who in some countries are already using this as an opportunity to clamp down on media freedom (p. 10).

The report noted a decline in the use of Facebook as a source of news and an increase in the use of messaging apps for news «as consumers look for more private (and less confrontational) spaces to communicate». Across all countries $44 \%$ of respondents said they trust most of the news most of the time, but only $34 \%$ said they trust news they find via search and only $23 \%$ said they trust the news they find in social media (p. 10). These attitudes reflect info-toxification.

Today, each bit of misinformation, like a little seed, lands in ground made fertile by growing distrust of authorities in general and the news media in particular as well as by skilled media manipulators who encourage their growth with new layers of misinformation and disinformation. What grows out of those plantings might bear little resemblance to the original information DNA, if you will, of its parent.

The size of the social media networks, with their billions of users, creates an ideal distribution platform. The instantaneous shared global communication and distribution of content by anyone anywhere is really new and different from the previous media disruptions of the printing press, radio, and television. Facebook is only 16 years old, YouTube 15, Twitter 14. TikTok, the short-video sharing app launched in China in 2016, has been downloaded over 1 billion times. These new distribution channels have created a new kind of communication with new kinds of problems that no single government or regulatory body has been able to control.

\subsection{SOWING Distrust as A POLITICAL STRATEgy}

The declining trust in information on the internet, which is now where most people get their news, plays into the hands of media manipulators who want to undermine the trust of democratic institutions. In many cases, the sources of misinformation are the countries who see western democracies, in particular the US, as their political and economic foes. A year after Donald Trump's election as president, the New York Times published an investigation that attributed disinformation about Hillary Clinton, his opponent, to «a cyber army of counterfeit Facebook and Twitter accounts, a legion of Russian-controlled impostors whose operations are still being unraveled» (Shane, 2017). Fast forward to October of 2020, and American intelligence and cybersecurity officials announced that Russia and Iran had obtained voter registration data and were attempting to interfere with the November election. The article quoted John Ratcliffe, the director of national intelligence: «This data can be used by foreign actors to attempt to communicate false information to registered voters that they hope will cause confusion, sow chaos and undermine your confidence in American democracy" (Barnes y Sanger, 2020). The only reason that this foreign interference could be detected was through efforts by cybersecurity experts from four different firms. In other words, amateurs lack the skills and tools to identify their manipulators. 


\subsection{BRITAIN'S 5G CONSPIRACY MONGERS: ENEMIES WITHIN AND WITHOUT}

In the spring of 2020, shortly after the covid-19 lockdown began in Great Britain, a fringe conspiracy theory that attributed damaging health effects to $5 \mathrm{G}$ cellphone towers began to spread rapidly. The theory had been around for a while, but the new twist was that it caused the virus. Social media and mainstream news outlets amplified the conspiracy theory to a population made vulnerable by all the disruption. Activists emboldened by the news fire bombed cellphone towers and attacked crews installing them (Waterson y Hern, 2020). A factchecking expert suggested that the roots of misinformation lay in Facebook and WhatsApp groups launched during the pandemic to help support neighbors. Google Trends data showed British interest in $5 \mathrm{G}$ exploded in the final days of March, shortly after the lockdown was imposed. «Less scrupulous news outlets» looking to boost traffic and the resulting ad revenue helped fan the flames, as did some celebrities looking to gain attention.

Meanwhile in the US, Russia's fingerprints could be found on theories about 5G's damaging health effects. Before covid-19, RT America, a Russian state-owned internet and cable-based news network, had been theories that linked $5 \mathrm{G}$ waves to brain cancer, autism, infertility, heart tumors and Alzheimer's disease, none of which have a basis in scientific fact (Broad, 2019). "Moscow's goal, experts say, is to destabilize the West by undermining trust in democratic leaders, institutions and political life. To that end, the RT network amplifies voices of dissent, to sow discord and widen social divides». RT America is carried on several American cable, satellite, and streaming outlets. Its YouTube channel has 1.1 million subscribers.

\subsection{Race WARfare AND violence incited on FACEBOOK}

Political operatives have not been the only ones making use of social media to foment division in society. In 2018, the United Nations Human Rights Council called for an independent investigation into violence against the Muslim Rohingya minority in Myanmar, specifically targeting Facebook's role in spreading hate speech (BBC, 2019). The investigation found that social media was a significant factor and that «Facebook has been a useful instrument for those seeking to spread hate, in a context where, for most users, Facebook is the Internet». It criticized Facebook for being «slow and ineffective» in eliminating hate speech. Facebook's product policy manager, Alex Warofka, was quoted in the report: «We agree that we can and should do more. We have invested heavily... to examine and address the abuse of Facebook in Myanmar ». He said Facebook was working on ways to make it easier to report and remove abusive content.

The New York Times also did a long-running investigation of Facebook's role in inciting vigilante justice and violence among hostile racial and ethnic groups in several countries, including Mexico, India, and Sri Lanka. A series of Facebook posts in Sri Lanka stirred up Sinhalese Buddhists to attack Muslims, to the point of burning a man to death in his home. At the root was a false accusation that a Muslim restaurant employee had put sterilization pills into the food and drink of Buddhist customers. After the post went viral, influential Facebook users mobilized their followers to commit violence against the Tamil-speaking Muslims. 


\subsection{THE PROFIT MOTIVE IN FALSE INFORMATION}

In the runup to the 2016 US presidential election, a series of investigative stories uncovered a veritable fake news factory in the town of Veles, Macedonia, where an army of young people, many in their teens, were paid to create false stories that appealed to supporters of Donald Trump (Tynan, 2016). The investigations revealed that some 150 such websites with American sounding names were posting their content on Facebook in order to generate clicks and advertising revenue. Trump supporters, it turned out, were enthusiastic spreaders of information, which resulted in profits for the writers and editors. These sites created the false story that Pope Francis was endorsing Trump, for example, and that the FBI was planning to indict Hillary Clinton over her use of email. Interviews with the website publishers and writers revealed that their only goal was making money. Experiments with left-leaning content revealed less interest from Facebook users. It wasn't worth the effort. Two years later, an investigation revealed that a lawyer in Veles who had launched several of the most popular sites had been getting help from pro-Trump political operatives in the US (Silverman, et al. 2018). So, in the end, politics also played a role. The Macedonia case illustrates the new nature of the genre in the digital age. False content can be created and spread, instantaneously, from anywhere in the world by anyone in the world at very little cost and with very high potential profit. This is a formula for a flood of falsehood or info-toxification.

\section{Defending public interest journalism and democracy}

The events of 2016 woke up traditional news media to the fact that it wasn't enough for them to just claim the moral high ground and expect the citizens of democratic societies to recognize their value. The established news media were facing a bigger threat. The flood of misinformation and propaganda was not only drowning out their voices but was also confusing news consumers to the point that they began distrusting all forms of news, as the Reuters Institute study showed. Journalism's status as pillar of democracy, the Fourth Estate, the source of trustworthy information and counterweight to political and economic power, was being eroded. Ordinary people were unable to distinguish legitimate news from misinformation, and many simply gave up, avoiding the news altogether. At the same time, thousands of newspapers closed for financial reasons all over the western hemisphere, leaving those communities with little or no coverage of events of public interest. Gradually, the news media began to recognize that the old model of advertising-subsidized journalism needed to evolve toward a user-funded public-service model. Many of them have begun that transition. In addition, civil society groups and politicians have begun to recognize the danger to democracy posed by uninformed communities and have been developing solutions.

\subsection{Government EFForts to CONTROL TECHNOLOGY PLATFORMS}

The European Union and its member states have been aggressively attempting to control Google and Facebook in particular, but most of those efforts have taken the form of fines 
for violating laws regarding taxes, privacy, data protection ( $\$ 122$ million against Facebook), or anti-competitive practices ( $\$ 5$ billion against Google). The EU does have a right-to-beforgotten standard dating to 2014, which requires search engines to remove sensitive personal information from results if a user requests it. However, Google successfully argued in the European Court of Justice that the standard should not apply to searches from outside Europe (Chee, 2019).

There are at least three problems with having governments regulate misinformation. First of all, it is hard to define. In authoritarian regimes, such as China, any information that conflicts with the party line is treated as disinformation and is quickly removed. Facebook, Twitter, and Google are all banned in China. Google actually pulled out of China in 2010 rather than censor its search results. On the other hand, in a democracy with a polarized political environment, one party's objective news report is another party's disinformation campaign. Chief executives of these same three internet companies were recently hauled before a US Senate committee to answer questions about a law that exempts them from responsibility for false or misleading information posted by their users (BBC, 2020). Republican Senators accused these internet giants of designing their algorithms to suppress conservative voices and favor liberal ones. The executives, of course, denied political motives. Their denials gain some credibility from an investigation by the political news website Politico and the Institute for Strategic Dialogue, a London-based nonpartisan think tank, which analyzed more than 2 million social media posts last summer. Their analysis found:

Right-wing social media influencers, conservative media outlets and other GOP supporters dominate online discussions around two of the election's hottest issues, the Black Lives Matter movement and voter fraud, according to the review of Facebook posts, Instagram feeds, Twitter messages and conversations on two popular message boards [Reddit and 4Chan] (Scott, 2020).

A second problem with putting the government in charge of managing disinformation is that regulatory agencies and public servants lack the training or access to the technology companies' databases to respond quickly enough to potentially harmful information, as became clear at the beginning of the covid-19 crisis. YouTube videos were a popular vehicle for misinformation about the virus. Susan Wojcicki, CEO of YouTube, questions whether government would have been able to respond as quickly as the platform itself did to the many inaccuracies that were popping up almost daily about covid-19. YouTube has hundreds of engineers specialized in monitoring and analyzing the site's traffic, so her strategy was to prevent channels with hoaxes from monetizing their content on the platform and removing them from recommendations (Levitt, 2020).

Wojcicki also addressed the third problem with government regulation, which is that it is extremely easy for a bad actor that has been banned from social media to create a new account under a new guise and resume production. Wojcicki believes that the platforms themselves are in a better position to understand the new technologies being used by these bad actors, reduce their visibility, and make it harder for them to spread inaccuracies. The creators of bogus content are quick to discover loopholes in the rules governing the platforms themselves, but the platforms are able to respond more quickly than government regulators, she said. 


\subsection{FOR-PROFIT EFFORTS TO ENSURE CREDIBILITY}

The private sector has recognized a potential profit opportunity in a growing demand for trustworthy information of public interest amid the sea of info-toxification. Any business that can reduce the cost of obtaining reliable information, in terms of time and money spent by users, has potential for profitability.

One of the most notable of these is a service called NewsGuard, which provides trust ratings on 6,000 websites that it says account for $95 \%$ of the engagement with news in the US, UK, France, Germany, and Italy. Co-CEOs Steven Brill and Gordon Crovitz are veteran journalists and entrepreneurs. According to the company's website, «NewsGuard's revenue comes from internet service providers, browsers, search engines and social platforms paying to use NewsGuard's ratings and nutrition labels in the news feeds and search results that they provide to their customers». Individuals can subscribe for $€ 2.95$ a month and access these ratings on a browser extension, plus they can see rating icons next to links on search engines, social media feeds, and other platforms: green means generally reliable and red means untrustworthy. They can also access more detailed ratings for each website based on five criteria for credibility (e.g. rarely produces false content, quickly corrects errors) and transparency (e.g. discloses ownership and financing, clearly labels advertising). NewsGuard's promotional material emphasizes that veteran journalists are responsible for developing the ratings and are constantly updating them.

In contrast with the labor-intensive method used by NewsGuard, Deepnews.ai uses algorithms to help identify quality and then has editors verify their ratings. Deepnews describes its mission as «building a system to spotlight quality journalism from the web, in real-time and at scale». The founder, Frederic Filloux, is a veteran French journalist and professor who began developing the algorithm during a sabbatical at Stanford University. Deepnews uses machine learning to improve its ability to predict which articles are of high quality based on many criteria, including the reputation and history of the journalist producing the work and the reputation of the publication they are writing for. Deepnews tests the algorithm regularly against the judgment of human editors and finds that the quality ratings are accurate about $80 \%$ of the time. Deepnews offers its service to publishers and advertising platforms. For example, news aggregators with high volumes of content can use the rating system to guarantee that the articles they are sending to clients are of high quality. An advertising platform can guarantee to advertisers that their ads will appear next to quality, trustworthy content.

\subsection{Public private partnerships, collaborations}

As the threat of info-toxification has grown around the world, more collaborations are emerging among news media organizations that used to view each other as competitors. There are more partnerships among for-profit and nonprofit news media, foundations, NGOs, and quasi-government organizations, generally under the label of public service journalism. The US has spawned many of these organizations, in part because it was hit early and hard by the disruption of the business model and partly because of a highly developed network of foundations, nonprofits, and philanthropy that provides services which in other countries are seen as, in economic terms, public goods and thus the responsibility of the state. 


\subsubsection{The International Fact Checking Network}

This network of some 200 members worldwide is based at the Poynter Institute in Florida and promotes basic standards through a code of principles. It also provides training for fact-checking organizations. In May 2020 the network launched a WhatsApp chatbot that people all around the world can use to debunk hoaxes through their personal connections. The network built a database of some 4,000 hoaxes around the pandemic with the help of fact checkers in 70 countries. The project's major funders include Facebook and the Google News Initiative (Singh, 2020).

\subsubsection{The Trust Project}

This is an international consortium of about 120 news organizations whose goal is to earn greater trust for their work by complying with eight standards of transparency and accountability, including who funds a site, best practices of news gathering, transparency of news sources, and actionable feedback. Members who comply are permitted to include the Trust Project's logo on their pages. Some notable participants include The Economist, The Globe and Mail, Italy's La Repubblica, Spain's El Pais, and Greece's Kathimerini. The project is funded by Google, Facebook, the John S. and James L. Knight Foundation, the Philanthropic Fund of Craigslist founder Craig Newmark, the Democracy Fund, and the Markkula Foundation.

\subsubsection{Google and Facebook fund journalism}

In addition to the projects already mentioned, these two internet giants have become major funders of ventures aimed at supporting high quality journalism and fighting misinformation, a fact loaded with irony, given that these two organizations more than any others have contributed to the collapse of the business model for news and the subsequent closing of thousands of news outlets around the world. Mathew Ingram explored this irony by interviewing many of the recipients of grants, often universities or nonprofit journalism organizations, who seemed aware that the contributions may have represented "guilt money" and a form of public relations to stave off regulators (Ingram, 2018). In 2015, Google set up the Digital News Innovation Fund with a commitment of $\$ 170$ million to support journalism in Europe, partly as a peace offering to publishers who were demanding that the search company pay for the use of snippets and headlines from their websites. A fifth of the those grants went to fighting disinformation. Later Google announced the commitment of another $\$ 300$ million over three years through the Google News Initiative, promising grants to programs aimed at strengthening quality journalism, developing sustainable business models, and developing technologies for journalism organizations. Facebook has also been making donations to journalism initiatives in Europe and the US, totaling some tens of millions of dollars.

\subsubsection{The Knight Foundation and election integrity}

The John S. and James L. Knight Foundation announced a commitment of \$3 million in grants to fight election disinformation, specifically to the aforementioned First Draft and Shorenstein 
Center, as well as Duke University (fact checking), and the Rochester Institute of Technology (tools for countering deep fakes) (Knight Foundation, 2020). The Foundation was motivated in part by a survey it commissioned from Gallup, which showed that four in five Americans were concerned that misinformation might sway the 2020 election.

\section{Conclusions/Discussion}

The elections of 2020 were a wakeup call to politicians, the news media, and society in general of the dangers of info-toxification. The pernicious impact of an avalanche of misinformation and disinformation, driven by the viral power of social media and search engines, became clearer, and so did the challenges for combating it. Part of the problem with combating misinformation is that it is hard to define from a legal point of view. Language and imagery are infinitely varied and subtle, and the messages that they convey are subject to infinite interpretation of what is true and what is false. Even facts can be twisted into falsehoods with deceptive framing. Add to this the fact that the telecommunications devices and technology distribution platforms make it possible for anyone anywhere with access to a smartphone or internet connection to create, alter, and share hoaxes and hate speech at the speed of light to a global audience. Existing legal and enforcement systems are unequipped to combat this kind of decentralized, diffuse enemy. Bad actors make enforcement even more complicated with their elaborate schemes to hide themselves behind multiple layers of disguise. Profiteers and propagandists take advantage of human beings' instinctive attraction toward headlines that promise humor, rumor, scandal, and warnings of imminent danger. Sensationalism has always been a lucrative media business model.

It is virtually impossible for journalists and regulators to take on each hoax. Explanations of why something is false require time and science; and logical, reasoned responses result in headlines that do not generate as much response as clickbait. Internet audiences are famously impatient. However, the info-toxification that society is suffering from has created a demand for trustworthy information. Both the marketplace and the public service sector have responded with solutions, which include rating the trustworthiness of media outlets and the information they provide. Part of the problem with misinformation lay with news organizations themselves, which have not been very transparent about their ownership, values, editorial personnel, methods, or sources. They also have not been very responsive to public criticism. Thus these new ratings of trustworthiness require media to be more transparent and allow the public to make their own judgments. They also require swift response to complaints and fulsome correction of errors.

A major unresolved problem is getting the technology platforms to cooperate more in solutions to the problems caused by misinformation. While they have been contributing some money toward solutions, their business model depends on a hands-off treatment of usergenerated content. The essence of their profitability depends on automating the processes of creation, distribution, and monetization. The platforms themselves have trouble policing content for the same reasons as others: misinformation is hard to define and technological tools are not adequate to identify or control it. YouTube users around the world add 720,000 hours of video daily: it would take an enormous, multi-skilled team fluent in hundreds of languages (remember the racial violence fomented in Sinhalese?) to police all those videos. 
Perhaps the most encouraging trend to emerge in response to info-toxification has been the growth of new partnerships that cross borders and bring together all interested parties: news organizations, civil society, politicians, regulators, academia, and private philanthropy, among others. Given that the internet platforms that have enabled hoaxes and conspiracy theories to thrive are global in scope, the efforts to counteract them must be global as well. The partnerships described above have a global scope and are adding partners all the time. At the moment, the bad guys are beating the good guys, if you will, but the good guys are catching up.

\section{Bibliography}

BARNES, Julian E. y SANGER, David E. (2020). «Iran and Russia seek to influence election in final days, U.S. officials warn». New York Times. Recovered from https://www.nytimes.com/2020/10/21/us/ politics/iran-russia-election-interference.html

BBC (2019). «Facebook admits it was used to 'incite offline violence' in Myanmar». BBC News, November

6. Recovered from https://www.bbc.com/news/world-asia-46105934

BBC (2020). «Facebook, Twitter and Google face questions from US senators». BBC News, October 28. Recovered from https://www.bbc.com/news/technology-54721023

BROAD, William J. (2019). «Your 5G phone won't hurt you, but Russia wants you to think otherwise». The New York Times, May 12. Recovered from https://www.nytimes.com/2019/05/12/science/5gphone-safety-health-russia.html

CHEE, Foo Yun (2019). "You have the right to be forgotten by Google, but only in Europe». Reuters. Recovered from https://www.reuters.com/article/us-eu-alphabet-privacy-idUSKBN1W90R5

INGRAM, Matthew (2018). «The platform patrons: how Facebook and Google became two of the biggest funders of journalism in the world». The Columbia Journalism Review, May 16. Recovered from https://www.cjr.org/special_report/google-facebook-journalism.php

KNIGHT FOUNDATION (2020). Knight Foundation announces nearly \$3 million for projects to help journalists combat information. Recovered from https://knightfoundation.org/press/releases/knightfoundation-announces-nearly-3-million-for-projects-to-help-journalists-combat-misinformation/

LEVITT, Steven D. (2020). «Hey, let's go buy YouTube». Freakonomics Radio [audio podcast]. Recovered from https://freakonomics.com/podcast/pima-susan-wojcicki/

MARWICK, Alice and LEWIS, Rebecca (2017). Media manipulation and disinformation online. Data \& Society Research Institute. Recovered from https://datasociety.net/wp-content/uploads/2017/05/ DataAndSociety_MediaManipulationAndDisinformationOnline-1.pdf

PEW RESEARCH CENTER (2019). Most Americans believe local news media are doing well financially, and few pay for it. Recovered from https://www.journalism.org/2019/03/26/for-local-news-americansembrace-digital-but-still-want-strong-community-connection/pj_2019-03-26_local-news_0-05/

SALAVERRÍA, Ramón, BUSLÓN, Nataly, LÓPEZ-PAN, Fernando, LEÓN, Bienvenido, LÓPEZ-GOÑI, Ignacio y ERVITI, María-Carmen (2020). «Desinformación en tiempos de pandemia: tipología de los bulos sobre la Covid-19». El profesional de la información, v. 29, n. 3, p. 10. DOI: 10.3145/ epi.2020.may.15

SCOTT, Mark (2020). «Despite cries of censorship, conservatives dominate social media». Politico, October 26. Recovered from https://www.politico.com/news/2020/10/26/censorship-conservativessocial-media-432643 
SHANE, Scott (2017). "The fake Americans Russia created to influence the election». The New York Times, September 7. Recovered from https://nyti.ms/2xdVuXM

SHORENSTEIN CENTER ON MEDIA, POLITICS AND PUBLIC POLICY (2020). The media manipulation casebook. Recovered from https://mediamanipulation.org/

SILVERMAN, Craig, FEDER, J. Lester, CVETKOVSKA, Saska y BELFORD, Aubrey (2018). «Macedonia's pro-Trump fake news industry had American links, and is under investigation for possible Russia Ties". BuzzFeed News, July 18. Recovered from https://www.buzzfeednews.com/article/craigsilverman/ american-conservatives-fake-news-macedonia-paris-wade-libert

SINGH, Manish (2020). «Poynter Institute launches WhatsApp chatbot to debunk coronavirus-related hoaxes». TechCrunch. Recovered from https://techcrunch.com/2020/05/04/poynter-institutesinternational-fact-checking-network-launches-chatbot-on-whatsapp-to-debunk-thousands-ofcoronavirus-related-hoaxes/

SWIFT, Art (2016). "Americans' Trust in Mass Media Sinks to New Low». Gallup. Recovered from https:// news.gallup.com/poll/195542/americans-trust-mass-media-sinks-new-low.aspx

TAUB, Amanda y FISHER, Max (2018). "Where countries are tinderboxes and Facebook is a match». The New York Times. Recovered from https://www.nytimes.com/2018/04/21/world/asia/facebooksri-lanka-riots.html

TYNAN, Dan (2016). «How Facebook powers money machines for obscure political news sites». The Guardian, August, 24. https://www.theguardian.com/technology/2016/aug/24/facebook-clickbaitpolitical-news-sites-us-election-trump

WARDLE, Claire (2017). «Fake news: it's complicated». First Draft. Recovered from https://firstdraftnews. org/latest/fake-news-complicated/

WATERSON, Jim y HERN, Alex (2020). «Perfect storm of conditions helped nonsense theories about 5G and coronavirus to take hold». The Guardian, April 7. Recovered from https://www.theguardian. com/technology/2020/apr/07/how-false-claims-about-5g-health-risks-spread-into-the-mainstream 